\title{
Moral philosophy, pragmatism, and the larger cause: why "war" metaphors are needed during pandemics
}

\author{
SOUMYADEEP BHAUMIK. SAMBIT DASH, KAMNA KAKKAR
}

\begin{abstract}
Coronavirus disease (Covid-19), which originated in China, is now a full-blown pandemic which has thrown governments and societies off-track in an unprecedented manner. War metaphors have been used widely to describe the scenario, but many critics decry them as harmful narratives. In this piece, we discuss the utility of the war metaphor to build solidarity and fraternity, which will be essential to get through the crisis. We also explain how concerns regarding increased authoritarianism and state excesses due to the use of these narratives are misplaced. We then tease out the colonial era concept of war that guides the arguments against the use of war metaphors in pandemics. We argue that in the post-modern world and in South Asian and African philosophies, wars are seen through the prism of the larger cause of dharma or ubuntu and that individual losses or gains in these contexts are part of a larger cause. The use of war metaphors reflects the need to get together for a societal cause. These metaphors are largely understood across societies while other alternatives are exclusionary, poetic and tangential in nature.
\end{abstract}

Keywords: Covid-19, pandemics, war metaphors, communication, philosophy, SARS-CoV-2

\section{Introduction}

Coronavirus disease (Covid-19), the global pandemic which originated in China, caught the world unprepared and is causing unprecedented distress, not only in terms of mortality and morbidity but also in its social, economic and political consequences. The media, politicians and communities globally were quick to adopt "war lingo" to describe the Covid-19 "battle". Consequently, several opinion pieces have been written about the supposed harms of using "war metaphors" during pandemics $(1,2)$. We discuss the pragmatic nature of war metaphors during pandemics, critically analyse

\footnotetext{
Authors: Soumyadeep Bhaumik (sbhaumik@georgeinstitute.org in - joint first author), The George Institute for Global Health, Elegance Tower, Plot No. 8, Jasola District Centre, New Delhi 110025 INDIA; Sambit Dash (corresponding and joint first author - sambit.dash@manipal.edu) Department of Biochemistry, Melaka Manipal Medical College, Manipal Academy of Higher Education (MAHE), Karnataka, INDIA; Kamna Kakkar (drkamnakakkar@gmail.com), Department of Anaesthesia, Pt. B. D. Sharma Post Graduate Institute of Medical Sciences, Rohtak, Haryana, INDIA.

To cite: Bhaumik S, Dash S, Kakkar K. Moral philosophy, pragmatism, and the larger cause: why "war" metaphors are needed during pandemics. Indian $J$ Med Ethics. 2020 Jul-Sep; 5(3) NS:219-21. DOI: 10.20529/JJME.2020.067.

Published online on June $11,2020$.

Manuscript Editor: Sandhya Srinivasan

(c) Indian Journal of Medical Ethics 2020
}

arguments against them, and present the philosophical and pragmatic case for their widespread adoption.

\section{Collective imagination needed for solidarity}

In the long history of the planet, humans have become the most dominant species in the labyrinth of evolution. As Yuval Noah Harari in his masterpiece Sapiens (3) elaborates, this dominance has been possible owing to the unique power of humans to connect, cooperate and collaborate with a large number of strangers for a common cause. The power of the collective imagination to visualise a greater cause have served us well as a species to "fight" physically superior wild animals. How best can we serve the rallying call which can capture the collective imagination of our species to "fight" a physically superior SARS-CoV-2? Thousands of years of evolution mean that we are well-conditioned to use the war-metaphor as a template for overcoming the greatest challenge we face in modern history collectively as a species. We need a rallying call which can capture the collective imagination - one that can work in Boston as well as in Bhatinda. There cannot be a better alternative than war metaphors for this purpose.

Governments cannot fight a pandemic of this nature and scale without the support of people. Being locked in the home for weeks together with no end in sight is indeed a sacrifice of individual liberty and freedom. However, the "war" metaphor makes people realise the enormity of the situation and ensures cooperation and psychological preparedness for the possible consequences - physical, social, and economic. The war metaphor helps in developing a strong sense of fraternity, providing some relief to an individual's suffering and agony. The spotlight on "warrior" healthcare workers also creates a window of opportunity for much-needed investment in human resources for health. In fact, in India, some state governments met the long-standing demand for better remuneration to "reward the frontline healthcare warriors" who bravely faced the heat of the pandemic $(4,5)$.

The war metaphors have also enabled solidarity internationally. When the UN Secretary General gave the call "...this war needs a war-time plan to fight it. Solidarity is essential. Among the G-20 - and with the developing world, including countries in conflict" (6), it resonated widely and was endorsed by 114 governments, regional organisations, religious leaders, civil societies and at least 16 armed groups (7).

\section{Concerns regarding authoritarianism and state excesses}

A key concern against the use of war metaphors in pandemics is the ample room that the war narrative provides for 
authoritarian leaders to exploit and curb individual liberty and free speech $(8,9)$. While we discuss the philosophical aspects of this argument later, it is important to highlight that the checks and balances on unbridled power during a crisis remain the same as in a non-crisis situation.

In a functioning democracy (with its judiciary, federal structure, autonomous institutions, opposition, civil society and the media) governments of the day will still have to face the people. This acts as a check on any excesses. The war metaphor around the pandemic has in-fact intensified solidarity across nations, which at other times is lost in the hustle and bustle of daily life. We have seen an example of this in India, where the urban middle class led civil society has been vocal about the plight of the migrant workers forcing the government to take some responsibility, something that has been missing all this while (10).

In fact, the solidarity built around the pandemic has made international communities more vigilant about excesses ordinarily deemed to be "internal matters" of the state. The recognition that all nations are allies in this battle has meant that politicians from the Gulf countries condemned the targeting of minorities as carriers of disease; thereby triggering clarifications by Indian officials (11). The examples cited by critics of the war narrative of repressive steps taken by Viktor Orban in Hungary (9) and Rodrigo Duterte in the Philippines (12), despite international and civil society criticism, are outcomes of an already failing political system in these countries. To pin these occurrences to the use of warmetaphors or even to the pandemic is an oversimplification of a complex context.

\section{The philosophy of war metaphors in pandemics}

To understand the value of war metaphors during pandemics, it is also essential to tease out the philosophy that guides the arguments for and against them. Those against them see war in a colonial context, wherein wars are acts of physical aggression to capture material resources. This concept of war is essentially rooted in 15th to 19th century Europe wherein aggressors fought battles to win colonies. Such massively aggressive exercises have not been part of South Asian and African traditions, which rather have been colonies for centuries.

In the post-modern world in which we live, battles are no longer fought solely with military might. Modern states do not fight wars with an all-bets-are-off colonial attitude. Modern wars are fought on multiple fronts using diplomacy, economics, narrative building, and non-state actors. A pandemic needs a multi-sectoral approach (13-15). The long arc for Covid-19 response demands a win-some lose-some approach to planning.

The Eastern traditional narratives that are internalised in the collective psyche of most of South Asia envisage the concept of war being tied to dharma, and as a means to the ends of peace and prosperity. War is thus seen as a duty which is in accordance with principles of dharma and the codes of war are woven into its narrative. The codes of this meta-physical war are woven into the narratives of popular epics. Entrenched within these epics are deeply held notions of sacrifice, honour and heroism $(16,17)$. African oral traditions, which have largely been neglected by the dominant colonial narrative around war ethics, are replete with accounts of the just war theory, nonviolent conflict resolution and the philosophy of ubuntu ("I am because we are") $(18,19)$.

In the classical Western construct, violation of codes of war is sanctioned provided it serves the "larger good" from the aggressor's perspective (20). However, in dharma and ubuntu, war is a multifaceted concept and so are the narratives woven around it. A war is not necessarily limited to a physical war where soldiers are killed, atrocities committed, and civil liberties suppressed. Even though some elements of these harms are bound to occur in dealing with a pandemic (the government after all creates containment zones, which are scientifically sound in principle but at the same time curtail liberties), the larger good is considered greater than the sum of these individual transgressions. Ubuntu or dharma provide the framework guiding what works for the collective, away from the colonial lens of individual gains or losses.

Using the colonial-era or European war lens to guide the choice of metaphors essentially disregards the "psychological, spiritual, communal, and social dimensions of illness and healing" (21). For a pandemic of such a huge scale, these consequences, perhaps, are more overwhelming to the society than the physical loss to individuals owing to the disease itself. Whatever metaphor we use, our health systems and the consequent stress that our healthcare workers will face will remain unchanged. War metaphors provide healthcare workers with the strength to cope with this situation (22). Being called a warrior is also meant to provide an assurance to their families that community solidarity will be available for the loss of a loved one. For a vast majority of individuals, being referred to as a warrior is a sign of recognition for putting societal causes over personal ones (22). Alternative softer narratives are divorced from the harsh reality, unlike war metaphors which recognise that personal sacrifices are indeed required for defeating a pandemic.

\section{Conclusion}

Abandoning war metaphors in pandemics is neither possible nor desirable. A viable question to ask is what alternative metaphor should we use in pandemic scenarios? "Climbing mountains", "cricket", "collaborative exploration", "journey of life" have all been suggested $(23,24)$. Such metaphors, which might be suitable for non-pandemic scenarios for specific disease groups or communities are largely exclusionary, poetic and tangential in nature. They run the risk of being lost on the public at large during such a crisis. While nuance in messaging is essential, the message stands to fail its purpose if the nuance is lost on the target audience, which in this pandemic, effectively includes all human beings. 
Using war metaphors for a pandemic not only reflects centuries of evolutionary conditioning and a pragmatic choice, it reflects a culture which sees war as a duty. Wars in eastern cultures are not framed in a narrow individualistic bracket. Wars thus are a means to the end of the greater good, and the use of war metaphors essentially serves the purpose of mobilising the largest number of people to end a pandemic.

Disclaimer: The opinions expressed in this article are those of the authors and do not represent those of their employers.

Conflict of interest and funding: The authors have no conflict of interest and no funding to declare.

\section{References}

1. Rohela P, Pathare S, Bhan A. 'War' on coronavirus is hurting doctors, health staff and you. New Indian Express. 2020 Apr 7 [cited 2020 May 11]. Available from: https://www.newindianexpress.com/opinions/2020/ apr/07/war-on-coronavirus-is-hurting-doctors-health-staff-andyou-2126724.html

2. Wise A. Military metaphors distort the reality of COVID-19. Scientific American Blogs. 2020 Apr 17[cited 2020 May 11]. Available from: https://blogs.scientificamerican.com/observations/militarymetaphors-distort-the-reality-of-covid-19/

3. Harari YN. Sapiens: A brief history of humankind. Random House; 2014. p 26

4. Kanwar S. Chandigarh: Monthly stipend of GMCH interns doubled to Rs 18,000. Times of India, Chandigarh. 2020 Apr 23[cited 2020 May 11]. Available from: https://timesofindia.indiatimes.com/city/chandigarh/ chandigarh-monthly-stipend-of-gmch-interns-doubled-to-rs-18000/ articleshow/75309357.cms

5. Special Correspondent. Coronavirus: Haryana doubles salary of doctors, nurses. Hindu, Chandigarh. 2020 Apr 10[cited 2020 May 11]. Available from: https://www.thehindu.com/news/national/coronavirusharyana-doubles-salary-of-doctors-nurses/article31303886.ece

6. UN Secretary-General's remarks at G-20 virtual summit on the Covid-19 pandemic. This war needs a war-time plan to fight it. Geneva: United Nations; 2020 Mar 26 [cited 2020 May 11]. Available from: https://www. un.org/en/coronavirus/war-needs-war-time-plan-fight-it

7. UN chief reiterates call for global ceasefire, debt moratorium to better cope with COVID-19. Xinhuanet. 2020 May 1[cited 2020 May 11]. Available from: http://www.xinhuanet.com/english/202005/01/c_139022106.htm

8. Musu C. War metaphors used for COVID-19 are compelling but also dangerous. The Conversation. 2020 Mar 19[cited 2020 May 11]. Available from: https://theconversation.com/war-metaphors-used- for-covid-19-are-compelling-but-also-dangerous-135406

9. Bruszt L. Viktor Orban: Hungary's disease dictator. Reporting Democracy. Balkaninsight.com. 2020 Apr 23[cited 2020 May 11]. Available from https://balkaninsight.com/2020/04/23/viktor-orbanhungarys-disease-dictator/

10. High Commissioner, UN Human Rights. COVID-19: UN human rights chief "distressed" over plight of India's internal migrants, welcomes measures to limit impact. Geneva: United Nation Human Rights; 2020 April 2[cited 2020 May 11]. Available from: https://www.ohchr.org/EN/ NewsEvents/Pages/DisplayNews.aspx?NewsID=25767\&LangID=E

11. Ganguly S. Blarel N. Why Gulf States are backtracking on India. Foreignpolicy.com. 2020 May 5[cited 2020 May 11]. Available from: https://foreignpolicy.com/2020/05/05/gulf-states-backtracking-india/

12. Smith T.Philippines: Rodrigo Duterte's dictatorship sinks to new depths with closure of main broadcaster. Conversation. 2020 May 8[cited 2020 May 11]. Available from: https://theconversation.com/philippinesrodrigo-dutertes-dictatorship-sinks-to-new-depths-with-closure-ofmain-broadcaster-138025

13. Marco MT, Baker ML, Daszak P, De Barro P, Eskew EA, Godde CM, et al. Opinion: Sustainable development must account for pandemic risk. Proc Natl Acad Sci. 2020 Feb 25; 117(8):3888-92.

14. Bhatia $R$, Abraham $P$. Time to revisit national response to pandemics. Indian J Med Res. 2020 Feb 1; 151(2):111.

15. Duggan J, Hayes C, Jilani M, Wurmel J, Connolly M. A multisectoral approach to identify innovative solutions to strengthen capacity building for pandemic risk management. Int J Infect Dis. 2016 Dec 1; 53:112-3.

16. Johnson JT, Patterson ED. The Ashgate research companion to military ethics. Routledge; 2016 Mar 23.

17. Evola J.Metaphysics of war: battle, victory \& death in the world of tradition. Arktos; 2011.

18. Cordeiro-Rodrigues, L African views of just war in Mandela and Cabral. Journal of Speculative Philosophy. 2018; 32(4), 657-73.

19. Appiah-Thompson C. The concept of peace, conflict and conflict transformation in African religious philosophy. Journal of Peace Education. 2019 Nov 7(3):1-25.

20. Dowd J. Maximizing dharma: Krsna's consequentialism in the Mahabharata. Praxis. 2011;3(1).

21. Nie JB, Gilbertson A, de Roubaix M, Staunton C, van Niekerk A, Tucker $J D$, Rennie $S$. Healing without waging war: Beyond military metaphors in medicine and HIV cure research. Am J Bioeth. 2016 Oct;16(10):3-11.

22. Goethals GR, Allison ST. Making heroes: The construction of courage, competence, and virtue. Adv Exp Soc Psychol. 2012; 46: 183-235.

23. Burnside JW.Medicine and war-A metaphor.JAMA.1983;249(15):2091. doi:10.1001/jama.1983.03330390083043

24. Parikh RB, Kirch RA, Brawley OW. Advancing a quality-of-life agenda in cancer advocacy: Beyond the war metaphor. JAMA Oncology. 2015 Jul $1 ; 1(4): 423-4$

\section{IJME is indexed on Pubmed, Scopus \& TPI.}

Articles from IJME, as also from the journal's previous titles Medical Ethics (1993-5), and Issues in Medical Ethics (1996-2003) are indexed on Pubmed. 